Vol. 2, No. 2, December 2021: p. 145-161. DOI: 10.18326/islah.v2i2.145-161

ISSN : $2723-407 \mathrm{X}$

Website: https://e-journal.iainsalatiga.ac.id/index.php/islah

\title{
The History of Islamic Values Internalization in Enhancing National Morality in Indonesia
}

\author{
Yassirly Amrona Rosyada \\ IAIN Salatiga \\ sirlynajmy@gmail.com
}

$\begin{array}{ll}\text { Submission Track: } & \\ \text { Received } & : 2021-10-15 \\ \text { Final Revision } & : 2021-11-05 \\ \text { Available Online } & : 2021-12-01\end{array}$

\begin{abstract}
Islam is a religion that teaches universal values or thoughts for all nations in the world. Those values can be combined with local culture or even the whole nation. For its universal values, Islam can be accepted by people in the world. Indonesia is one of the countries which can accept and integrate Islamic values with local culture or National values. Moreover, Walisongo and Ulama spreading Islamic values in Indonesia played an important role in internalizing Islamic values. By using various methods and techniques, they internalize Islamic values in enhancing moral in Indonesia trough trading, education, Sufism, politics, culture, and arts. In conclusion, Islamic values act as a source of moral treasury of Indonesian people, a balance between religion and culture, a motivator, a dynamist, and an innovator of Indonesian people.
\end{abstract}

Keywords: History, Islamic Values, National Morality

\begin{abstract}
Abstrak
Islam merupakan agama yang mempunyai ajaran atau nilai-nilai yang bersifat universal untuk seluruh bangsa di dunia. Nilai-nilai Islam dapat berpadu dengan budaya lokal maupun berpadu dengan nilai-nilai seluruh bangsa. Dengan sifat keuniversalan nilai-nilai Islam, maka agama Islam dapat diterima oleh semua penduduk di dunia. Indonesia, merupakan salah satu Negara yang dapat menerima dan memadukan nilai-nilai Islam dengan budaya lokal atau nilai-nilai bangsa Indonesia. Sejarah awal bangsa Indonesia yang sangat berperan dalam internalisasi nilai-nilai Islam pada bangsa Indonesia adalah walisongo dan para ulama penyebar agama Islam di Indonesia. Melalui berbagai macam cara dan teknik, mereka menginternalisasikan nilai-nilai Islam pada pembinaan moral bangsa Indonesia. Baik melalui jalur perdagangan, pendidikan, tasawuf, politik, maupun melalui budaya dan kesenian. Pada akhirnya, nilai-nilai Islam dapat berperan sebagai sumber perbendaharaan moral bangsa Indonesia, dapat berperan sebagai penyeimbang antara agama dan budaya, serta dapat berperan sebagai motivator, dinamisator, maupun innovator bangsa Indonesia.
\end{abstract}

Kata Kunci: Sejarah, Nilai-Nilai Islam, Moral Bangsa. 
The History of Islamic Values Internalization in Enhancing...(Yassirly Amrona Rosyada)

\section{INTRODUCTION}

Brought by the Prophet Muhammad PBUH in the VII century AD, the arrival of Islam is considered by historians as the construction of the New World which include new thoughts, new ideals, new culture and new civilization. ${ }^{1}$ The "New World" concept which was brought along with the spread of Islam was marked by the mixing between local principles/teachings/culture/civilization and universal Islamic teachings and values.

Islam spread in the world. It eventually brought together local civilizations around the world with the universal Islamic teachings. It also happened in Indonesia. Consisting of thousands of islands, Indonesia has varied ethnic groups and cultures. Giving a special identity, the cultural and ethnic diversity becomes the basic capital in the development of the nation's culture.

The emerging between civilization or local culture with Islam forms a national morality. Although there are some disagreements, the reality forces to unite. In Indonesian, it is originally known as Bhinneka Tunggal Ika Tan Hana Dharma Mangrwa which means the spirit that is willing to acknowledge and believe the truths from wherever it may be.

The history in Indonesian begins with the existence of a cultural mixing with Islam which is well-known as a religious nation who believes in the existence of God. ${ }^{2}$ The morality of a nation is constructed based on the religion and the culture. In contrast, the early history of Indonesian was full of animism and dynamism.

The emerging between civilization or local culture with Islamic values in Indonesia was carried out by preachers from various countries. In the end, the phenomenon happened in Java. The spread and development of Islamic values with local values is carried out by wali who are well known as Walisongo.

Walisongo had special media in spreading and constructing Islam in Java including arts, languages, teachings, and etc. The teachings and values that were spread and constructed by Walisongo are still alive in the midst of the society. This is the beginning of

\footnotetext{
${ }^{1}$ Musyrifah Sunanto, Sejarah Peradaban Islam Indonesia (Jakarta: Rajawali Pers, 2012), iv, p. 1.

${ }^{2}$ This can be seen from the Preamble of the 1945 Constitution of the Republic of Indonesia which is clarified in one of its articles. The Law was amended several times regarding to the people's religion and belief. See Article 29 paragraph subsection (1) "Negara Berdasar atas Ketuhanan Yang Maha Esa”, dan bagi masyarakatnya dibebaskan untuk memeluk agama atau kepercyaannya serta beribadat menurut agama atau kepercayaan tersebut,". See Article 29 paragraph subsection (2) and Article 28 E paragraph subsection (1) and (2). The Constitutional Court of the Republic of Indonesia, the 1945 Constitution of the Republic of Indonesia, and the Law of the Republic of Indonesia number 24 of 2003 on The Constitutional Court ((Jakarta: Sekretaris Jenderal Mahkamah Konstitusi Republik Indonesia, 2006), p. 80-82.)
} 
the milestone of internalizing Islamic values in the moral development of the Indonesian nation.

\section{METHODOLOGY}

This paper discusses the history of Islamic values internalization in enhancing moral in Indonesia, including the research model qualitative research which examines the literature as the data sources. The data were collected and classified based on the theme. A description was carried out based on the theme. Finally, the analysis and conclusions were made. This qualitative research describes how the history of Islamic values internalization in enhancing moral in Indonesia.

\section{DISCUSSION}

\section{The History of Islamic Values Assimilation into Indonesia}

Islam assimilated into Indonesia started in the 7th century AD. Islam spread widely around the 12th and 13th centuries AD. The spread did not occur at the same time. In Java, it occurred in the 11th century $\mathrm{AD}$ proven by the discovery Fatimah bint Maemun tomb at Gresik which was made, as the researcher believed, in $475 \mathrm{H} / 1082 \mathrm{AD}{ }^{3}$ However, there was also historical data stating that Islam assimilated into Java around the 12th century or 13th century AD. ${ }^{4}$

Besides the Fatima binti Maimun tomb, the tomb of the Persian cleric named Malik Ibrahim which was also found and dated to $882 \mathrm{H}(1419 \mathrm{AD})$ is a proof that at that time Gresik's people had embraced Islam. Therefore, at the time of King Kertawijaya (1447M), it was assumed that there were nobles and courtiers who embraced Islam ${ }^{5}$.

There were several ways for spreading Islamic values in Indonesia including:

1. Muslim's Traders from Arab, Persia, and India

The Islamic preachers from various countries who come to Indonesia include traders. Whle they wait for the next seasons to go to another area, they preach to spread Islam. Through this trade route, Islam could be accepted by upper class people, such as royal officials, ship owners, and regents.

\footnotetext{
${ }^{3}$ Fatah Syukur, Sejarah Peradaban Islam, (Semarang: PT. Pustaka Rizki Putra, 2009), p. 190.

${ }^{4}$ Dedi Dupriyadi, Sejarah Peradaban Islam, (Bandung: Pustaka Setia, 2008), p. 191.

${ }^{5}$ Fatah Syukur, p. 191.
} 


\section{Sufism}

Sufism is an Islamic teaching explaining dzauq of humans or creatures to the khaliq. These teachings are carried out by people who have the qualities of being protected from worldly covetousness. In Islam, as it has several similarities with the indigenous people who previously adhered to Hinduism, it could be easily accepted by the community. Sunan Kalijaga was good at combining local values of the Indonesian people by inserting Islamic teachings with the nuances of Sufism. ${ }^{6}$

3. Education

Education means a way to gain a knowledge. Therefore, the Indonesian people, who at that time were still classified as ignorant, needed education. This was what Islamic preachers used to spread Islamic teachings. Educational sector played a very good role in spreading Islam since it was integrated with community activities. For example, education activities conducted in mosques (suraus) and pondok pesantren.

The spread and enhanced of Islam carried out by Walisongo can be seen through education. This was inferred from Walisongo's activities in establishing pesantren done by Sunan Ampel, Sunan Giri, and Sunan Bonang.

Sunan Ampel founded a pesantren in Ampel Denta (near Surabaya) which became the first center for spreading Islam in Java. His students included Raden Paku (Sunan Giri), Raden Makdum Ibrahim (Sunan Bonang), Raden Kosim Syarifuddin (Sunan Drajat), Raden Patah (who later became the first sultan of the Kerajaan Islam Demak), and Maulana Ishak.

Furthermore, Sunan Giri founded a pesantren in Giri. Many of his students come from low-income groups. He sent educated preachers to various areas outside Java such as Madura, Bawean, Kangean, Ternate and Tidore.

Moreover, Sunan Bonang concentrated his education and da'wah activities through pesantren which was established in Tuban. Sunan Bonang gave an in-depth Islamic education to Raden Fatah, the son of the king of Majapahit, who later became the first sultan of Demak. These educational records are now known as Suluk Sunan Bonang.

\footnotetext{
${ }^{6}$ Sumanto Al Qurtuby, Arus Cina-Islam-Jawa, (Yogyakarta: Inspeal Ahimsakarya Press, 2003), p. 113.
} 
Pesantren became an institution for spreading Islam in Java, which had a direction for determining Islamic character on Islamic kingdoms, and played an important role for spreading Islam to remote areas. $^{7}$

4. Politic

In politics, Islam began to position itself when the power of Majapahit weakened. This weakness gave the Islamic rulers on the coast an opportunity to build independent power. Under the leadership of Sunan Ampel, Walisongo agreed to appoint Raden Patah as the first king of the Islamic kingdom of Demak as the first Islamic kingdom in Java.

Another political way carried out by Muslims was through politics done by Islamic Kingdom opposing non-Islamic kingdoms was disliked by the people. With the Islamic kingdom victory, many royal officials converted to Islam, so that many people were influenced by royal officials who finally decided to convert to Islam. ${ }^{8}$

Several wali or sunan became royal advisors, and Sunan Gunungjati became king. Through political means, Islam could spread and enhance rapidly in Java. Sunan Ampel was very influential in Majapahit. His wife came from the palace, and Raden Patah (son of the king of Majapahit) was his student. Sunan Ampel's closeness to the palace made the spread of Islam in Java easy, and got the blessing of the royal rulers. Sunan Giri was the giver of blessing in the coronation of the king. Sunan Kalijaga was also an advisor to the Demak Bintoro Ssultanete.

5. Arts

Arts such as wayang performances and Javanese songs were effective for spreading Islam. The story of wayang is partly taken from Mahabharata and Ramayana which includes Islamic values. As wayang is integrated in society, wayang performances influence among Javanese people to converts to Islam.

Walisongo spread and enhanced Islam by preaching around from one area to another. Sunan Muria, in his da'wah efforts, always visited remote villages. The da'wah carried out by Walisongo was seen through arts. They took advantage of traditional arts as a medium of Islamic da'wah by inserting Islamic values. Through this art, the wali inserted the teachings tauhid and worshiping Allah.

\footnotetext{
${ }^{7}$ Nur Syam, Islam Pesisir, (Yogyakarta: PT. LKis Pelangi Aksara, 2005), p. 69-75.

${ }^{8}$ Badri Yatim, Sejarah Peradaban Islam, (Jakarta: Grafindo Persada, 1994).
} 
Sunan Kalijaga was famous as a wali who was engaged in the arts. He spread and developed Islam through gamelan, wayang kulit, and baju takwo. Sunan Ampel created Pegon letters (Javanese language with Arabic script). The letters are still used in Pesantren as material for Islamic religious lessons. Sunan Giri created tembang dolanan anak with Islamic nuances. Sunan Drajat also created a Javanese song, that is still popular, entitled Gending Pangkung. Sunan Bonang was considered as the first creator of gending for developing Islamic teachings in East Java. In spreading Islam, he always adapted to the cultural style of Javanese people who loved wayang and gemelan music.

The da'wah method used by Sunan Giri wasthrough the arts by creating Jetungan games, Tembang Jamuran, Tembang gula ganti, Tembang Cublak-cublak suwen, Tembang Asramarandhana, and Tembang Pocung. ${ }^{9}$

6. Marriage

The merchants or traders who come from overseas and were Muslims lived in a place for a long time. Besides, they even married local princess or woman. This marriage then made them and their sons converted to Islam.

\section{Islam and National Morality}

Islam is one of samawi religions revealed by Allah SWT through His Messenger, Prophet Muhammad PBUH. The word "Islam" derived from Arabic language "aslama yuslimu Islam" which has several meanings. According to Abdul Karim, based on Encyclopedia of Islam, some of the meanings are ${ }^{10}$

1) Freeing oneself from any mental and physical ailment;

2) Surrendering, subduing, or obeying oneself wholeheartedly; and

3) Merging into salam including salvation, prosperity, peace, harmonious relationship, or purity state.

The essence of Islam is to surrender or to obey wholeheartedly to Allah SWT for the sake of achieving a purity state, harmonious and peaceful relationships with others, or prosperous in this world and the hereafter.

\footnotetext{
${ }^{9}$ Purwadi dan Enis Niken, Dakwah Wali Songo, (Yogyakarta: Panji Pustaka, 2007), p. 105.

${ }^{10}$ M. Abdul Karim, Islam Nusantara (Yogyakarta: Gama Media, cetakan revisi 2013), p. 15.
} 
Islam was brought by Muhammad PBUH as a way of life. He taught many things about human life without forgetting the afterlife. Islamic teachings are based on Al Qur'an and al-Hadith. These sources are universal to be applied to all Muslims anywhere and anytime. The universality of Islamic teachings is applicable with the local culture or human civilization in the world. Muslims in Arab world and Indonesia hold Islam as their religion and teachings, and understand the teachings of Islam based on Al Qur'an and Sunna.

The majority of Indonesians are Muslims. Islamic teachings have a significant impact on Indonesian people life including social, political, and civilization sectors. This is due to the value of Islamic teachings that are accepted by Indonesian people.

Some values brought by Islam in Indonesia are accepted by the population including:

1. Islam teaches the existence of an afterlife that related to this life;

2. Islam teaches its adherents to be responsible for their own life in afterlife; and

3. Islam teaches rules and norms in social and national context in accordance with maintaining world Muslim solidarity.

The teachings to Islam adherent to regulate their life to act cautiously in the world as there are good and bad rewards for their deeds in the hereafter. The second value teaches Muslims to believe and practice legal norms and the correct moral guidance. Moreover, the third value shows that human beings are not classified into ethnic groups, but the classification depends on their faith. Those three Islamic values encourage people to establish the right basis for living, think and do the right things, and organize things properly. ${ }^{11}$

Discussions about morals are generally identical to ethics or akhlaq. The following explanation describes the definition of each of the words above.

Akhlaq which is derived from Arabic language is a plural form of khuluqun that means character, temperament or behavior. It is equivalent to the word khalqun as they are from word khalaqa which means creation. The last word is related to khaliq (fa'il) that means the creator, and makhluq (maf'ul) that means the created. ${ }^{12}$

\footnotetext{
${ }^{11}$ Gustave E. Von Grunebaum (Ed.), Islam Kesatuan dalam Keragaman, terj. Effendi N. Yahya (Jakarta: Yayasan Obor Indonesia, 1983), p. 26.

${ }_{12}$ Hamzah Ya'qub, Etika Islam Pembinaan Akhlaqul Karimah (Suatu Pengantar) (Bandung: CV. Diponegoro, cet. vi, 19993), p. 11-12.
} 
The word etika is derived from English language "ethics" which means the science of morality determining how humans should live in society including what is good and what is bad. ${ }^{13}$ Ethics is also derived from Greek ethos which means custom. ${ }^{14}$

Moral is from Latin moralis concerning morality (mores). The plural form of mores is mos which means custom. ${ }^{15}$

According to Amin Abdullah, morals and ethics are related to the good and bad of human actions, but different in meanings. In short, he explains that morals are the good and bad values of every human action, while ethics is the study of a good and bad action. Therefore, ethics acts as the theory of good and bad deeds ('ilm al akhlaq), and morals (akhlaq) is the practice. ${ }^{16}$

Talking about national morality, Abdul Karim explains that national morality shows how the attitudes, behavior, and actions of a nation. National morality in Indonesia is a crystallization of the various existing morals derived from local customs and several religions in Indonesia. In the historical record of Indonesia, it is found that the process of developing morals in Indonesia was influenced by Islamic morals (akhlaq) combined with morals that was grown and developed from Indonesian culture. ${ }^{17}$

\section{Islam is a Religion of Morality}

Morality is equivalent with akhlak in Arabic language. Prophet Muhammad PBUH sent by Allah SWT acts as a morality or akhlak completion. This can be seen from Al Qur'an and Sunna explaining that Prophet Muhammad PBUH has noble character and is assigned to complete human morals and brings them into a good civilization.

One of the verses of Al Qur'an showing the word akhlak and explaining that Prophet Muhammad PBUH is a role model for humans for His morals is written in Surah (68) al Qalam: 4.

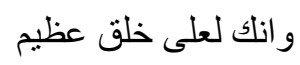

"And indeed, you are of a great moral character."

\footnotetext{
${ }^{13}$ Karim, Islam, p. 21.

${ }^{14}$ Ya'qub, Etika, p. 12.

${ }^{15}$ Karim, Islam, p. 21, dan Ya'qub, Etika, p. 14.

${ }^{16}$ Amin Abdullah, Antara al-Ghazali dan Kant: Filsafat Etika Islam (Bandung: Mizan, 2002), p. 15.

${ }^{17}$ Karim, Islam, p. 75.
} 
Meanwhile, the word akhlaq as stated in Hadith of the Prophet Muhammad PBUH narrated by Imam Ahmad is described as one of the main tasks of Him. He is the completion, guide and director of moral completion. As He said ${ }^{18}$

$$
\text { بعثت لأتمم مكارم الاخلاق }
$$

"I have been appointed as prophet of God for the completion and perfection of moral ethics"

Islamic values on morals are also found in Tawhid. It is a subject of aqidah and faith. Moral or akhlaq are related to human actions. The relationship between the two is that faith is not only in someone's heart, but applied in real actions in the form of good deeds or good behavior. Therefore, the true faith is a faith that results good deeds or good morals.

The words of Prophet Muhammad PBUH as narrated from Abu Hurairah ra says:

$$
\text { اكمل المؤمنين ايمانا احسنهم خلقا }
$$

"The most perfect believer in his faith is the one who has the most excellent manners"

Therefore, it is clear that morality in Islam must be based on faith. For example, shyness is a part of good morals, and Prophet Muhammad PBUH teaches shyness as a part of one's faith. ${ }^{19}$. The relationship between moral teachings and other Islamic teachings such as tawhid emphasizes that Islam is a religion of morality.

\section{Internalizing Islamic Values in Enhancing National Morality in Indonesia}

Islam is a perfect religion with life guidance for humans in several aspects including akidah, worship, akhlak, and muamalah. The perfection of Islam has been determined by the All-Knowing and AlMighty God, Allah SWT, in His word Surah al Ma'idah (5) verse 3:

$$
\text { اليوم اكملت لكم دينكم و اتمدت عليكم نعمتى ورضيت لكم الاسلام دينا }
$$

“... This day I have perfected for you your religion and completed My favor upon you and have approved for you Islām as religion..."

The perfection of Islam is like the perfection of life itself. In life, there is motion and dynamics resulting changes and developments every time from one stage to another, from one color to another in the dimension of time that continues without stopping.

\footnotetext{
${ }^{18}$ Ya'qub, Etika, p. 12.

${ }^{19}$ Ya'qub, Etika, p. 18.
} 
Even though Islam is built on solid and permanent foundations, it retains eternal truth. The truth can guide humans in their lives to keep moving and changing all the time masa. ${ }^{20}$ Here, it lies the perfection of Islam as stated in verse 3 of Surah al-ma'idah (5) above. Islam will always move and develop in accordance with human civilization including human morals.

Islam came to Indonesia with moral values based on Al Qur'an and Sunna which have a realistic basis in life. It is natural when Islam came to Indonesia with its Islamic moral values and was accepted by the Indonesian people without opposition. In contrast, when Islam came to Indonesia, this country had deeply embedded to Hinduism and Buddhism in civilization and human morals.

With the arrival of Islam, Indonesian society underwent a transformation from a feudal agrarian society of Hindu-Buddhist heritage to an urban society of Islamic influence. The arrival of Islam became an intellectual enlightenment that did not exist during the Hindu-Buddhist period. ${ }^{21}$ As a place of trading for foreigners, there is acculturation of culture, language, political, social, and economic systems of several foreigners living in Indonesia ranging from immigrants from Gujarat, India to Arabian Peninsula.

The arrival of foreign Muslim citizens made Islam began to spread and develop in Indonesia. There are several roles of Islam in the moral development of Indonesian nation, including:

\section{a. The Source of Morality}

Moral which is called Akhlaq al-Karimah in Islam is based on Al Qur'an and Hadith of Prophet Muhammad PBUH. Then, there is a role for scholars to make ijtihad and understand God's intentions. Islamic morality fills the void left by others such as secular morals which are only outward in nature, or Sufis which are only inward. ${ }^{22}$

The role of Islam to fill the moral sources is seen from its values based on Al Qur'an and Sunna. For example, there are the source of one's spiritual progress, the guide of goodness, the perfection of Faith, virtue in the Hereafter, primary needs in the family, and harmony between neighbours. The Islamic values above are for the moral

\footnotetext{
${ }^{20}$ Ali Yafie, Menggagas Fiqh Sosial Dari Soal Lingkungan Hidup, Asuransi, Hingga Ukhuwah (Bandung: Mizan, cet.ii, 1994), p. 62.

${ }^{21}$ Sunanto, Sejarah, p. 4-5.

22 Karim, Islam, p. 175.
} 
development of the nation, so that they have noble character in associating with others and in developing the country. ${ }^{23}$

In Islam, science can improve humans in their spiritual progress because knowledgeable people are close to their God and are exalt in degree among people. As the word of Allah SWT, in Surah Fatir verse 28, which means " Only those fear Allah, from among His servants, who have knowledge." and Surah al Mujadalah verse 11 which means " Allah will raise those who have believed among you and those who were given knowledge, by degrees. And Allah is Aware of what you do".

Islamic morals are also a guide to goodness and a source in fostering the nation's morals. Morals are not only about good and bad, but also bring benefits to fellow human beings. As the words of Prophet Muhammad PBUH narrated by Imam Bukhari and Muslim is "Indeed the best among you is the one with the best character".

Islamic morals are a manifestation of the perfection of faith. People who have noble character are an indicator of perfect faith and vice versa. The words of Prophet Muhammad PBUH narrated by Imam al-Tirmidhi states " The most perfect believer in his faith is the one who has the most excellent manners, and the best of you are those who are best to their wives".

The Islamic treasury for the moral development of the nation is stated in the poem said by Syauqi Bik: ${ }^{24}$

$$
\text { و انما الامم الاخلاق ما بقيت * وان همو ا ذهبت اخلاقهم ذهبوا }
$$

"Nations are strong with their morals, if these morals gone they gone"

The historical journey of Indonesian independence is a proof that Islamic morals have a major role in the moral development of the Indonesia. The movements carried out by the Indonesian people for national independence were mostly carried out by Muslims. ${ }^{25}$ By noble morals based on the understanding on Islamic values (based on $\mathrm{Al}$ Qur'an and Sunna), Indonesian Muslims fight against the tyranny of the invaders who act arbitrarily, oppress the poor, and so on.

\footnotetext{
${ }^{23}$ Ya'qub, Etika, p. 23-30.

${ }^{24}$ Ya'qub, Etika, p. 30.

${ }^{25}$ Karim, Islam, p. 176.
} 


\section{b. Culture and Religion Balancing}

Islam is believed by its adherents to guarantee the realization of a human life that is physically and mentally prosperous. In Islam, there are various instructions on how humans should respond to this life in a more meaningful way.

The Islam instructions regarding the joints of human life are the source of its very great teachings. For example, instructions teach to have noble character, prioritize brotherhood, love cleanliness, be balanced in meeting their material and spiritual needs, as well as other positive attitudes.

Islam, as a series of socially institutionalized value systems, has an important role in cultural transformation because Islam composed of normative elements demands our answers at various levels of thought, feeling and deed. The directive system is seen from its urgency to preserve society, maintain it in front of humans in the sense of giving value to humans, and instill a human basis for it.

Considering transformative function as the functions of religion for society, the important role of religion in cultural transformation is increasingly difficult to doubt. Religion, in fact, always changes old values by instilling new values which will eventually give birth to a new order of people's lives. ${ }^{26}$ This arrangement is expected to be in line with the changing times and in accordance with the wishes of the community.

In Islam, this transformative function is manifested through the intensity of Islam in changing as well as directing society gradually towards the ideal order, civil society. $^{27}$

The spread of Islam cannot stop and exist outside the reality of human life. Islam must regulate all aspects of human life. Islam with its teachings regulate the entire system of life in this world. Since Islam regulates all human behavior towards himself, others, and his Lord (hablumminallah wa hablumminannas), it is natural that ulema in their books regulate all human behavior. This setting, for example, regards to eating procedures, drinking, studying, having good manners towards each other, praying, fasting, hajj, husband-wife relationship, and criminal law.

\footnotetext{
${ }^{26}$ Hendropuspito, Sosiologi Agama (Yogyakarta: Kanisius, cet. xii, 1996), p. 56.

27 The term civil society is used by Dawam Raharjo to call khairu ummah referring to Madinah people when Prophet Muhammad PBUH set the life there. M. Dawam Raharjo, Masyarakat Madani: Agama, Kelas Menengah dan Perubahan Sosial (Jakarta: LP3ES, 1999), p. 29,34.
} 
The relationship between human beings in Islam is regulated in fiqh mu'amalah. Rules for interacting, choosing friends, choosing culture, negotiating, buying and selling and so on as long as it involves two or more people, are regulated in fiqh mu'amalah. Social relations that cannot be separated from certain community forms and characteristics are also regulated in it as a representation of the role of ulema towards the community.

The existence of Islam in Muslim community, both individually and socially, does not form a monolithic community or culture. ${ }^{28}$ Islamic community in a certain area is different from the Islamic community in other areas. Therefore, the cultural values are different from each other with their respective diversity. Islam has provided opportunities for its adherents to maintain, shape, and develop their respective cultures, as long as they do not violate the universal principles of Islam. ${ }^{29}$ Here, there is a cultural transformation effort in accordance with the character of a dynamic culture as the result of human tasteand work.

The intersection between Islam and culture actually existed since Islam was born. For example, the text of Al Qur'an as a record of revelations sent down by Allah through the angel Gabriel to the Prophet Muhammad PBUH. was a text from the results of culture. ${ }^{30}$ Therefore, understanding Al Qur'an must go through various approaches that do not rule out social, cultural and scientific areas, so that the text always lives in society. $^{31}$

The culture, beliefs, and rituals of a nation have emerged along with the development of society itself. In Indonesia, the beliefs, rituals and culture adopted by the community were first based on animism ${ }^{32}$ and dynamism, ${ }^{33}$. For example, those practiced by the Javanese people is Slametan, Surtanah or geblak to protect from evil

${ }^{28}$ Sidi Gazalba describes the inseparable relationship between Islam and culture as there are two elements in Islam, worship and mu'amalah which means religion and culture. Sidi Gazalba, Masyarakat Islam Pengantar Sosiologi dan Sosiografi (Jakarta: Bulan Bintang, 1976), p. 82-93.

${ }^{29}$ Muhammad Sulthon, "Interelasi Nilai Jawa dan Islam Perspektif Ekonomi", dalam Darori Amin (ed.), Islam dan Kebudayaan Jawa (Yogyakarta: Gama Media, 2000), p. 247.

${ }^{30}$ Read further Nasr Hamid Abu Zaid, Mafhum an-Nash Dirasah fi Ulum al-Qur'an (Beirut: al-Markaz atsTsaqafi al-Arabi, 2005). V.

${ }^{31}$ Muhammad Syahrur, al-Kitab wa al-Qur'an Qira'ah Mu'atsirah (Beirut: Aidah al-Ahali, 2000), vi, p. 51-63.

32 Beliefs in the existence of spirits in moving objects such as humans, animals and plants. Kuncoroningrat, Sejarah Kebudayaan Indonesia (Jakarta: Djambatan, 1954), p. 103.

${ }^{33}$ Beliefs in the existentence of spirits in inanimate miniature objects such as akik, keris, and etc.. Kuncoroningrat, p. 341. 
spirits. $^{34}$. Then Hinduism and Buddhism came and coloured the diversity of the nation's behavior. It is followed by Islam ${ }^{35}$, Christianity, and, global civilization. Those are unavoidable in globalization where all forms of activity can be identified in a minute, influence the crucial areas.

The majority of Indonesian people are Muslims, so religious teachings, both moral and legal, are the manifestations of Islam values. Islamic morals act as a balance between culture and religion. Religion should not shackle cultural development, and culture should not exceed religious values.

Religion is not culture as the secular view. Religion and culture go hand in hand in the moral development of national morality. ${ }^{36}$

\section{c. Motivators, Dynamists, and Innovators in Facing Challenges}

The role of Islam in educating morals in Indonesian is also as a motivator, dynamist, and innovator. As a motivator, the role of Islam is seen from ijtihad carried out by ulema in finding Islamic teachings based on Al Qur'an and Sunna, so they can be used for the advancement of the nation's moral civilization. Moral that grows in Indonesian based on Islamic teachingsa are

1. Labor morals in which labor must be based on consensual consent or 'an taradhin. Moreover, workers' salaries must be paid before their sweat dries.

2. Trade morals in which buying and selling system paid in credit including loans must be written down and witnessed. The word of Allah SWT, in Surah al Baqarah (2) verse 282:

يا أيها الذين آمنوا إذا تداينتم بدين إلى أجل مسمى فاكتبوه وليكتب بينكم كاتب بالعدل ولا يأب كاتب أن يكتب كما علمه الله

\footnotetext{
34 Ismawati, "Budaya dan Kepercayaan Jawa Pra-Islam", dalam Darori Amin (ed.), Islam dan Kebudayaan Jawa (Yogyakarta: Gama Media, 2000), p. 7.

35 Regarding to the history of the spread of Islam in Java, there are still some different opinions among historians. The concrete evidence states that Islam existed in Java in the $11^{\text {th }}$ century by the discory of Fatimah binti Maimun tomb who died on 7 Rajab $475 \mathrm{H}$ or December 1st, 1082 AD. Anasom, "Sejarah Masuknya Islam di Jawa", dalam Darori Amin (ed.), Islam dan Kebudayaan Jawa (Yogyakarta: Gama Media, 2000), p. 28-29.

36 Karim, Islam, p. 178.
} 
"O believers! When you contract a loan for a fixed period of time, commit it to writing. Let the scribe maintain justice between the parties. The scribe should not refuse to write as Allah has taught them to write."

3. Interactional Morals in which humans have the same position before God, while the level of their glory lies in their piety. The words of the Prophet Muhammad PBUH narrated by Imam al Bukhari and Imam Muslim ${ }^{37}$ :

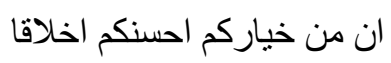

"The most perfect of you is the one who has the most excellent manners"

Furthermore, as a dynamist, Islamic morals are not rigid which causes fanaticism in its adherents. Islamic morals do not stop at a certain place and time. For example, regarding the development of aircraft manufacturing, airplane passengers are not allowed to carry their luggage beyond the specified size. The language of Al Qur'an and Sunna is compiled with various variations, such as the mutasyabihat verse and the muhkamat verse. ${ }^{38}$

Islamic morals are also innovators as it provides opportunities for the adherents to think ahead and be open. As stated in Al Qur'an that Muslim need to pay attention to the signs of God's power in the heavens and on earth. ${ }^{39}$ Indonesia has developed this scientific progress for the benefit of the nation and religion such as the construction of LAPAN and the observatory in Boscha, Lembang, Bandung. This institution advances science especially in astronomy, including Islamic astronomy.

\section{CONCLUSION}

Islam is a religion that teaches universal values which is able to assimilate temporaland local culture and civilization. The internalization of Islamic values in Indonesia has been carried out by ulema who spread Islam in Indonesia. There are several routes of dissemination as the internalization of Islamic values in the Indonesian nation, namely through marriage, Sufism, arts and culture, education, politics and so on.

\footnotetext{
37 Ya'qub, Etika, p. 25.

38 Karim, Islam, p. 183-184.

39 Karim, Islam, p. 184-185.
} 
The internalization of Islamic values in the nation's moral development can be seen in various ways including as the source of national morality, as religion and culture balancing, and as a motivator, dynamist, and innovator for the Indonesian nation.

\section{REFERENCE}

Abdullah, Amin. Antara al Ghazali dan Kant: Filsafat Etika Islam. Bandung: Mizan, 2002

Abu Zaid, Nasr Hamid, Mafhum an-Nash Dirasah fi Ulum al-Qur'an. Beirut: al-Markaz atsTsaqafi al-Arabi, 2005

Anasom, "Sejarah Masuknya Islam di Jawa", dalam Darori Amin (ed.), Islam dan Kebudayaan Jawa. Yogyakarta: Gama Media, 2000

Dupriyadi, Dedi, Sejarah Peradaban Islam, Bandung: Pustaka Setia, 2008

Gazalba, Sidi. Masyarakat Islam Pengantar Sosiologi dan Sosiografi. Jakarta: Bulan Bintang, 1976

Grunebaum, Gustave E. Von (Ed.), Islam Kesatuan dalam Keragaman, terj. Effendi N. Yahya. Jakarta: Yayasan Obor Indonesia, 1983.

Hendropuspito, Sosiologi Agama. Yogyakarta: Kanisius, 1996

Ismawati, "Budaya dan Kepercayaan Jawa Pra-Islam”, dalam Darori Amin (ed.), Islam dan Kebudayaan Jawa. Yogyakarta: Gama Media, 2000

Karim, M. Abdul .Islam Nusantara. Yogyakarta: Gama Media, 2013

Kuncoroningrat, Sejarah Kebudayaan Indonesia. Jakarta: Djambatan, 1954

Mahkamah Konstitusi Republik Indonesia, Undang-undang Dasar Negara Republik Indonesia tahun 1945 dan Undang-undang Republik Indonesia Nomor 24 tahun 2003 tentang Mahkamah Konstitusi. Jakarta: Sekretaris Jenderal Mahkamah Konstitusi Republik Indonesia, 2006

Purwadi dan Enis Niken, Dakwah Wali Songo, Yogyakarta: Panji Pustaka, 2007

Qurtuby, Sumanto Al, Arus Cina-Islam-Jawa, Yogyakarta: Inspeal Ahimsakarya Press, 2003

Raharjo, M. Dawam. Masyarakat Madani: Agama, Kelas Menengah dan Perubahan Sosial. Jakarta: LP3ES, 1999 
Simon, Hasanu, Misteri Syekh Siti Jenar, Yogyakarta: Pustaka Pelajar, 2004

Sulthon, Muhammad. "Interelasi Nilai Jawa dan Islam Perspektif Ekonomi", dalam Darori Amin (ed.), Islam dan Kebudayaan Jawa. Yogyakarta: Gama Media, 2000

Sunanto, Musyrifah, Sejarah Peradaban Islam Indonesia, Cet. IV, Jakarta: Rajawali Pers, 2012

Sunanto, Musyrifah. Sejarah Peradaban Islam Indonesia. Jakarta: Rajawali Pers, 2012

Syahrur, Muhammad. al-Kitab wa al-Qur'an Qira'ah Mu'atsirah. Beirut: Aidah al-Ahali, 2000

Syam, Nur, Islam Pesisir, Yogyakarta: PT. LKis Pelangi Aksara, 2005

Syukur, Fatah, Sejarah Peradaban Islam, Semarang: PT. Pustaka Rizki Putra, 2009

Ya’qub, Hamzah. Etika Islam Pembinaan Akhlaqul Karimah (Suatu Pengantar). Bandung: CV. Diponegoro, 1993

Yafie, Ali. Menggagas Fiqh Sosial Dari Soal Lingkungan Hidup, Asuransi, Hingga Ukhuwah. Bandung: Mizan, 1994

Yatim, Badri, Sejarah Peradaban Islam, Jakarta: Grafindo Persada, 1994 
The History of Islamic Values Internalization in Enhancing...(Yassirly Amrona Rosyada) 